\title{
Microscopy and Development of a Remarkable Pitted Quill from the Thin-Spined Porcupine, Chaetomys subspinosus
}

\begin{tabular}{|c|c|}
\hline Journal: & Canadian Journal of Zoology \\
\hline Manuscript ID & cjz-2017-0281.R2 \\
\hline Manuscript Type: & Article \\
\hline $\begin{array}{r}\text { Date Submitted by the } \\
\text { Author: }\end{array}$ & 01-Mar-2018 \\
\hline Complete List of Authors: & $\begin{array}{l}\text { Chapman, D.M.; } 27 \text { Rupert St. } \\
\text { Giné, Gastón; Úniversidade Estadual de Santa Cruz, Departamento de } \\
\text { Ciências Biológicas } \\
\text { Roze, Uldis; Queen's College, City University of New York, Biology }\end{array}$ \\
\hline $\begin{array}{r}\text { Is your manuscript invited for } \\
\text { consideration in a Special } \\
\text { Issue?: }\end{array}$ & Not applicable (regular submission) \\
\hline Keyword: & $\begin{array}{l}\text { Chaetomys subspinosus, thin-spined porcupine, quill, DEVELOPMENT < } \\
\text { Discipline, ULTRASTRUCTURE < Discipline, Energy Dispersive X-ray } \\
\text { Spectrometry, Fourier Transform Infrared Spectrometry }\end{array}$ \\
\hline
\end{tabular}

\section{SCHOLARONE Manuscripts}




\section{Microscopy and Development of a Remarkable Pitted Quill from the Thin-Spined \\ Porcupine, Chaetomys}

David M. Chapman, Gastón A. F. Giné and Uldis Roze

David M. Chapman*, Adjunct Professor of Chemistry, Lakehead University, 955 Oliver Road, Thunder Bay, ON, P7B 5E1 Canada

G.A.F. Giné, Departamento de Ciências Biológicas, Universidade Estadual de Santa Cruz, Rodovia 415 Ilhéus-Itabuna, Km 16-Salobrino, CEP 45662-900, Ilhéus, Bahia, Brazil gastongine10@gmail.com

U. Roze, Department of Biology, Queens College CUNY, Flushing, NY 11367, USA uldis.roze@verizon.net

*Corresponding author: David M. Chapman, Adjunct Professor of Chemistry, Lakehead University, 955 Oliver Road, Thunder Bay, ON, P7B 5E1 Canada. Preferred home contact: 27 Rupert St. P7B 3W4, 807-345-5941 dchapman@tbaytel.net 
Abstract: Scanning electron microscopy shows that the quill surface from the thin-spined porcupine (Chaetomys subspinosus (Olfers 1818)) has several regional cuticular patterns of which the most expansive is highly pitted with $4-\mu \mathrm{m}$ wide pores leading to pits, which in turn communicate circumferentially via tunnels to neighboring pits. The cell unit of the pitted layer is a hexagonal or pentagonal prism, the 'pitted fibrillous cuticular cell' (PFCC), which has a superficial pitted cuticular scale-derived part with an underlying part packed with fine fibrils and the nucleus. The scaled part has about six scales, which swell and fuse except where raised cuticular scales from the inner root sheath intervene. This unique and complicated cell soon dies even while below the skin's surface during its development. The raised scale-bearing cells of the inner root sheath leave their imprints on the PFCC's surface thus indicating that the quill's pitted layer is at one time soft. Histochemistry, Energy Dispersive X-ray Spectrometry and Fourier Transform Infrared Spectrometry show that the PFCC is keratinous.

Key words: development, Chaetomys subspinosus, thin-spined porcupine, quill, cuticle development, ultrastructure, scanning electron microscopy, Energy Dispersive X-ray Spectrometry, Fourier Transform Infrared Spectrometry

\section{Microscopie et Dévelopment d'un Piquant Persé et Remarquable du Porc-Épic Épineux,}

\section{Chaetomys subspinosus}

Resumé: La microscopie électronique à balayage montre que la surface des piquant Chaetomys subspinosus a plusieurs sortes de régions cuticulaires dont la plus grand est fortement marquée de 4- $\mu \mathrm{m}$ large pores conduisant à des puits, qui a son tour communiquent via des tunnels à la circonference des puits voisins. Cette cellule est une prisme hexagonale ou pentagonale, la 
“Cellule Cuticulaire Fibrillaire Percée" (CCFP), qui a une partie superficielle de six écailles et une partie sous-jacente emballée des fibrilles minces et le noyau. Entre ces écailles se trouvent les écailles élevées de la gaine interne de la racine folliculaire. Ensuite les écailles des CCFP gonflent et entourent les autres écailles. Cette cellule unique et compliquée (CCFP) meurt tôt en dessous de la surface de la peau pendant son développement. Les cellules de la gaine intérieure laissent leurs empreintes sur la surface de la CCFP indiquant ainsi que la surface était douce puis plus dure. L'histochemie (Dispersion d'Energie Spectrométrie à Rayons X et Transformation de Fourier Infrarouge Spectrométrie) montrent que la CCFP est composé de kératine. La signification fonctionelle de cette cellule est inconnue.

Mots-clés: Chaetomys subspinosus, porc-épic épineux, development de la cuticule, épic, microscopie électronique à balayage, Dispersion d'Energie Spectrométrie à Rayons X, Transformation de Fourier Infrarouge Spectrométrie, microscopie électronique à balayage 


\section{Introduction}

Porcupines are famous for their defensive and, occasionally, offensive spines (Roze 2009). The histochemical and chemical properties of quills as well as the associated piloerector muscles and dermal components of the skin have been studied in detail in Erethizon (Chapman and Roze 1997; Roze 2002; Cho et al. 2012). Quills from Erethizon have recurved barbs anchoring the quill in the predator; also, there is a facilitated release mechanism separating the basal end of the impaled quill from the porcupine (Chapman and Roze 1997; Roze 2002). Surprisingly, barbs facilitate tissue penetration and have inspired the design of less traumatic hypodermic needles (Cho et al. 2012).

By contrast, no studies have examined details regarding the quills of other species of New World porcupines, as is the case of the thin-spined porcupine (Chaetomys subspinosus Olfers, 1818), with only some general descriptions of the quills and pelage in the literature (Emmons and Feer 1997; Eisenberg and Redford 1999; Nowak 1999; Roze 2012). Earlier observations showed the thin-spined porcupine does not have barbed quills (Roze 2012), as is also the case in members of the Hystricidae (Old World porcupines). Nowak 1999 writes, "The pelage of most of the back is peculiar, the hairs being more like bristles than spines. The hairs of the head, neck, and forelimbs, however, are spinelike and less flexible than those on other parts of the body." Eisenberg and Redford 1999 concur saying that the 'spines' on the dorsum are not as stiff as those of true porcupines.

Chaetomys subspinosus quills invite detailed study for two reasons. First, this species is the most divergent and basal member of the family Erethizontidae, the New World porcupines, containing 16 species. Chaetomys is the sole member of the subfamily Chaetomyinae, a clade whose separation apparently occurred in the Late Oligocene to the Early Miocene, some 21 
million years ago (Vilela et al. 2009; Voss et al. 2013). The remaining 15 members of the Erethizontidae are all members of the Erethizontinae, comprised of the genera Coendou and Erethizon. This taxonomy is based on substantial evidence in the form of sequencing and careful morphological comparisons (Vilela et al. 2009; Voss 2011; Voss et al. 2013; and Pontes et al. 2013).

The second reason for the study of Chaetomys is its precarious conservation status. Despite its biological uniqueness, insufficient measures are being taken to protect the animal. This species is listed as vulnerable to extinction (International Union for the Conservation of Nature 2014) due mainly to high levels of deforestation and consequent loss of habitat in its species range. The thin-spined porcupine lives in the Atlantic Forest of Brazil (Santos et al. 1987; Oliveira et al. 2012), a biome highly disturbed by human settlement (Ribeiro et al. 2009). This medium-sized (1.3-2.7 kg) rodent species (Chiarello et al. 1997; Oliveira et al. 2012) is nocturnal, arboreal and folivorous (De Souto Lima et al. 2010; Giné et al. 2010; Giné et al. 2012; Oliveira et al. 2012). It is also opportunistically hunted by local people mainly for the meat (Castilho et al. 2013).

Hunters describe Chaetomys as less well defended than the sympatric porcupine, Coendou insidious, because Chaetomys is slower, its quills are softer and don't come loose when an aggressor attacks (Castilho et al. 2013). The barbless quills are tan, relatively thick and short on the head, neck and upper back; farther back on the sides and rump, they are long and slender suggesting that the pelage of most of the back does not contribute to the physical defense of the animals (Giné et al. 2012; Giné personal communication 2015).

Porcupine quills and typical mammalian hairs (see Discussion) are homologous in that they have the basic cellular layers of cuticle, cortex and usually a medulla; furthermore, they are 
derived from a cylindrical epidermal ingrowth (Elias and Bortner 1975). The hair types on the dorsum of Erethizon have been described (Chapman and Roze 1997), but information on the microscopic aspects of the quills of the thin-spined porcupine has never been published. Here we describe the cytology, histochemistry and development of the quills of this monotypic and threatened neotropical porcupine.

\section{Materials and methods}

Specimen

The skin specimen of Chaetomys subspinosus is from a sub-adult, the remains of a predation event from the municipality of Una $\left(38^{\circ} 58^{\prime}-39^{\circ} 22^{\prime} \mathrm{W} ; 15^{\circ} 02^{\prime}-15^{\circ} 23^{\prime} \mathrm{S}\right)$ in Bahia State, Brazil. The gender and weight of the animal are unknown. The specimen was fixed in phosphatebuffered formaldehyde for a few days, then transferred to $70 \%$ ethanol for subsequent treatment. Quills at low magnification

A plucked quill from the upper back is drawn (Fig. 1a) and others from the head, neck, upper back, and mid-back are shown (Fig. 2a).

To visualize the quill's surface, a quill was set on a slide and placed on the stage of a compound microscope, then illuminated by a beam of oblique light. The percentage of the quill's length having a pitted surface was calculated.

Staining, Microscopy and Chemistry of the Pitted Fibrillous Cuticular Cell (PFCC)

Pitted fibrillous cuticular cells make up most of the distal region along the quill and it is this cell that is of interest in this study. The dead, mature PFCC, as we will show, has a superficial part composed of about six cuticular scales studded with surface pores, and a basal 
part packed with fibrils as well as the cavity representing the vacant site of the former nucleus. We stress that the six scales and basal part constitute a single cell as we will show.

Physicochemical methods

On morphological grounds alone, the surface of a hair or quill may be assumed to be a keratinous structure; however, the PFCC region is so different from other such surfaces that chemical tests were deemed necessary. Two physicochemical methods were used on the PFCCs. The first method involved different shaved levels of the quill and EDX (energy dispersive x-ray spectrometry), which gave a localized elemental analysis of the PFCC. A strong signal for sulfur is indicative of keratin while a signal for nitrogen is associated with the amino acids making up keratin's protein. The other method is FTIR (Fourier Transform Infrared, using the FT-IR Spectrometer Tensor 37, Bruker Optics) of the quill's pitted surface, which compared the IR spectrum of the quill's surface with that of the human nail.

Dane and Herman's 1963 technique distinguishes between soft and hard keratin. Other histochemical methods given below can reveal the broad chemical nature of the cell.

\section{Staining and histochemistry}

A range of histochemical methods was used to characterize the PFCC. The periodic acidSchiff technique for non-substituted hexose-containing mucosubstances with cis-vicinal glycols (Pearse 1968); sulfated mucopolysaccharides by Alcian Blue (Pearse 1968); for DNA, the Feulgen reaction (Pearse 1968); and, masked as well as unmasked lipids by Sudan Black (Wigglesworth 1971). Melanin granules were identified using 0.1\% Methylene Blue in water at $\mathrm{pH}<1$ based on Lillie 1955.

Masson's trichrome, a histological technique (Grimstone and Skaer 1972), demonstrated the tissue components well. [Nuclei, black (Iron Haematoxylin); collagen and mucus, green (Fast 
Green FCF); muscle and cytoplasm, pink (Ponceau 2R)]. Masson's trichrome after Gurr (1952) used Aniline Blue instead of Fast Green FCF.

Histogenesis of the quill takes place in the subcutis, hence tissue blocks, $10 \mathrm{~mm}$ x $10 \mathrm{~mm}$ $\mathrm{x} 4 \mathrm{~mm}$ thick, were embedded in paraffin. Sections, 8-10 $\mu \mathrm{m}$ thick, were stained in the following: Heidenhain's Iron Haematoxylin (Galigher and Kozloff 1964) used progressively demonstrated the PFCC's fibrils.

Because the cytoplasmic fibrils of PFCCs resemble Actinomyces we tested for these bacteria. Tests used were Nile Blue Sulfate (Gurr 1952) for the bacteria and picric acid for keratin (Gurr 1952). Also for bacteria, we used Orcein (Humason 1979).

For photomicroscopy, a Motic Images Plus digital camera was used on a Zeiss (Oberkochen/Wuertt) Ultraphot II microscope.

\section{Scanning electron microscopy}

Our Hitachi SU70 scanning electron microscope gave high-resolution views of intact or cut surfaces. For a quill's sub-surface features, a segment was glued to a stub with epoxy cement then sliced to various depths longitudinally using a scalpel. Similarly, transverse segments were studied. Paraffin sections cut at $25 \mu \mathrm{m}$ were expanded on warm water, mounted on stubs previously coated with $0.1 \%$ gelatin and left to dry before heating on a warm plate at $50^{\circ} \mathrm{C}$ overnight. Specimens were dewaxed in xylene, then transferred to hexamethyldisilazane (Nation 1983) then left to dry, and finally, gold-coated for scanning electron microscopy.

Quills were partially macerated with paratoluene sulfonic acid (Kassenbeck 1979). This allows one to easily see the surface cell borders of the pitted region.

A pitted quill segment was chemically dissected by rocking a forceps-held quill in 5.5\% $\mathrm{NaOCl}$ at room temperature for two minutes before washing in water. This powerful oxidant 
removes the pitted layer revealing the deeper fibrillous layer. The segment was affixed to a stub and gold-coated.

\section{Polarizing microscopy}

The birefringence of sections of the quill in its pitted region and inner sheath layers was examined under crossed analyzer and polarizer. This is a simple method giving high contrast fine structural information in fibrous structures.

\section{Results}

Quill overview

Figure 1a is a survey sketch of a neck quill. Its smooth distal unbarbed tip is $\sim 1 \mathrm{~mm}$ long then wavy and pitted followed by an unpitted gently curved region towards the base. The most basal part is the thin 'neck' with its anchoring slightly bulged cylinder-shaped end.

From Fig. 2a the quill from the head is densely covered distally with minute pits for $72 \%$ of its distal surface; the neck, 63\%; upper back, 58\%; mid-back, $81 \%$; tail base, 71\%; and, side, 76\%. The latter two are not shown.

The quill surface as viewed by light and scanning electron microscopy

A 38-mm long upper back quill was examined. The pitted region is shown in Figs. 3a and b. Faint scale borders occur. The pores are 3-5 $\mu \mathrm{m}$ wide. The scales are slanted distally.

Circumferential cracks are present in dried specimens over the distal half of the pitted region and can extend down into the pits and even the cortex. In thinner quills from the back and sides, a longitudinal crack can extend down to the medulla. All these are probably desiccation artifacts. 
The pitted surface can be readily scraped away with a scalpel because of its chalky and porous nature.

Figures (2b,c,d and e) show the pits tilted distally. A pit cavity is slightly wider at its mid-region (Fig. 2e). Groups of 3-9 pits are enclosed in elongated cuticular areas with raised longitudinal and circumferential ridges as in Fig. 3a. These areas are interpreted as the imprints of scale-bearing cells of the inner root sheath (See Discussion). Even the micro-sculpturing of surface dimples on the quill (Fig. 3b) corresponds to micro-bumps on the inner root sheath (Fig. $2 \mathrm{~g}$ ). The cuticular scales' surface fusion lines are usually between the scales of the pitted layer, but some fusion lines are at right angles laterally between adjacent scales.

This region's inner root sheath cell has 3-9 strap-like jutting scales with more in the midrange. These sheath scales become surrounded in the pitted layer and retain their shapes as noted when the inner root sheath is peeled from the quill (Fig. 2d,f). Later in a pit, an inner root sheath scale (Fig. 2h) disintegrates (Fig. 3b) leaving an empty pit (Fig. 3a). Nothing is seen to occupy the pits later. Sometimes the internal root sheath is retained for a short distance beyond the skin's surface (Fig. 2i.)

The axial widths of the quills' cuticular scales were measured along two axial rows. Row $\# 1:$ mean $=6.4 \mu \mathrm{m}$, s.d. $=1.45 \mu \mathrm{m}$, range $=4.2-7.5 \mu \mathrm{m}, n=7$. Row \#2: mean $=6.3 \mu \mathrm{m}$, s.d. $=$ $2.08 \mu \mathrm{m}$, range $=3.0-9.0 \mu \mathrm{m}, n=7$. Partial maceration (Kassenbeck 1979) of the scales makes such measurements easy (Fig. 2b).

The PFCC is about $38 \mu \mathrm{m}$ long. Knowing the cuticular scale's exposed slanted surface axial width $(6.3-6.4 \mu \mathrm{m})$, the number of scales per cell is six. 
The diameters of quill pores from four inner root sheath imprints on the pitted surface were combined. Mean $=3.5 \mu \mathrm{m}$, s.d. $=1.30 \mu \mathrm{m}, \mathrm{n}=21$. The smallest diameter in the field of view was $1.4 \mu \mathrm{m}$ while the widest was $6.3 \mu \mathrm{m}$.

An Iron Haematoxylin section of a $28-\mu \mathrm{m}$ thick PFCC has a $13-\mu \mathrm{m}$ thick pitted outer part making up $46 \%$ of the cell's thickness. Deeper is the 15 -mm thick (54\%) fibrillous compartment. The fibrillous compartment of the pitted cell

In the living PFCC the fibrillous compartment is lined by a Ponceau 2R-staining layer about $0.6 \mu \mathrm{m}$ in thickness. Its outer layer next to bottom of the pits is jagged.

Scanning electron microscopy shows the fibrillous compartment packed with branching fibrils, 0.1-0.2 $\mu \mathrm{m}$ in diameter (Fig. 4d). Fibrils take up about half the volume of the cell near the surface of the compartment where they are directed to the surface (Fig. 4c) as already noted by light microscopy. In the deeper three quarters, the branching fibrils are matted in different directions, but parallel to the base. Towards the cell's base there is progressive fusion of the fibrils.

The $\mathrm{NaOCl}$ treatment reveals these fibrillous compartments with the fibrils, nuclear sites and cell borders (Fig. 4e). Borders are less resistant to the hypochlorite than the fibrils.

The Feulgen test showed that PFCC nuclear DNA is confined to one or two large nuclei in the fibrillous compartments of those PFCCs very near the root's basal end where differentiation takes place.

\section{Quill development}

One way to understand a complicated biological structure is to follow its development. All that was necessary here was to find the stage (Fig. 2c) preceding the PFCC's final stage (Fig. 2d). Figure 2c shows how both the inner root sheath's scales and those of the PFCC interdigitate 
without pits or circumferential tunnels. The later Fig. 2 d shows walled pits and tunnels.

Interpretation of these findings is in the Discussion. Figures $2 \mathrm{c}, \mathrm{d}$ and $\mathrm{f}$ show the development of the quill's inner root sheath and PFCC.

\section{Staining, histochemistry and chemistry of the quill}

An early PFCC cuticular scale is covered by a plasma membrane. Inside the scale on the outer side is the epicuticle layer (Fig. 2h) then deeper, the endocuticle. (See Swift 1981;

Hashimoto 1988 and Forsland 1990 for cuticular cytology.)

The pitted and fibrillous layers are negative with the Periodic acid-Schiff test indicating a lack of $c i s$-vicinal hydroxyls characteristic of many carbohydrates.

Orcein is negative for elastin and Actinomyces.

The Nile Blue/picric acid method stained the fibrillous layer pale green but lacked intense blue linear forms, which would have indicated Actinomyces.

We compared the well-known staining of the mammalian epidermis with the PFCC. The Phloxine B-Orange G method stained the porcupine’s skin's basal epidermal layers reddish orange (soft keratin) and the superficial layers the redder hard keratin. In the PFCC the pitted and fibrillous layers are both orange indicating soft keratin.

In the spot mode, EDX shows a strong signal for sulfur and a weak one for nitrogen in the pitted layer, the fibrillous layer and the cortex suggesting keratin. Fourier Transform Infrared Spectrometry shows the scan for human keratin is the same as for the pitted layer's surface (Fig. 5). These physical methods are critical methods for keratin.

The Sudan Black test for masked or unmasked lipid is negative. Alcian Blue for sulfate groups is negative. The Feulgen method for DNA is positive for PFCC nuclei only in the basal region of the follicle. 
Methylene Blue in acidic water stained granules in the pitted cell dark blue, indicating melanin. These granules are variable in occurrence from cell to cell. Granules can occur in the fibrillous part mainly towards the side and base. In scales, they are mainly located at the distal tips and bases. The color of the pitted layer is a matte dull greyish tan, a color due, in part, to melanin.

\section{Birefringence}

The cortex is strongly birefringent as determined by polarizing microscopy.

In a PFCC scale the pitted layer's epicuticle is very faint, and its deeper endocuticle, negative. The basal compact layer of the fibrillous compartment is negative, but the superficial layer with its radially aligned fibrils, is weakly positive indicating form birefringence.

\section{Discussion}

\section{Basics of hair development}

We find that the major histological details concerning the layers in the Chaetomys, quill are similar to the much smaller human hair (Fig. 1f). The following aims to clarify their complicated histogenesis.

Briefly, the development (anagen phase) of a hair involves a bulb of dividing cells, which are extruded as a narrowing cylinder towards the skin surface. The cells in this cylinder differentiate into an outer, thin imbricated cuticle of a monolayer of thin cells, a middle substantial layer, the cortex composed of longitudinal rods and, finally, usually a central core, the medulla, made up of cylindrical to polyhedral air-filled cell remnants. The hair's major chemical component is keratin (Fawcett, 1994). Hairs, bristles and quills are built on this common plan. 
In the histology of the human anagen follicle (Junqueira and Carneiro 2005: Hashimoto 1988) it is easy to identify the cuticular cells of the hair and inner root sheath as they differentiate. About half way along the follicle and central to the glassy membrane (basement membrane next to the dermis), the following layers of the keratogenous zone are noted. The next layer in is the living stratified rather cuboidal external root sheath, which is continuous with the skin's epidermis. This layer does not move towards the skin's surface as do the next layers, which progressively differentiate then die.

Further inwards, the internal root sheath has three layers of which the outermost one is Henle's layer consisting of one early keratinized stratum buttressing the softer more internal cells. There are frequent intercellular gaps allowing easy access of nutrients to the metabolically active cells of the developing hair. The middle layer is Huxley's layer of one to three cells packed with large trichohyalin granules. The nuclei and lateral cell borders are difficult to see. Finally there is the cellular cuticle of the inner root sheath with usually overlapping imbricated scales whose free edges point basally. The ascending inner root sheath desquamates in the follicular canal well before the skin surface.

Covering the definitive cortex are its cuticular cells, but here its scales tilt distally. The two cuticles interlock as part of the hair's anchoring mechanism.

The keratogenous zone is preceded by a deeper zone of cell growth and early differentiation.

Our focus is on the quill type of hair. Some other hair types among mammals are the fine long fetal lanugo, the short fine velus, underfur, guard hairs, vibrissae, bristles, and awns.

We describe for the first time the cytology, histochemistry and development of the quills of the thin-spined porcupine, and find, quite surprisingly, that a special surface region has unique pitted complex keratinized cells not found in other porcupines. We name these cells the Pitted 
Fibrillous Cuticular Cells. These unprecedented PFCC cells within the family Erethizontidae corroborate the high degree of phylogenetic separation of this species within the family (Vilela et al. 2009; Voss 2011; Voss et al. 2013). Since porcupine quills and human hairs are homologous structures (Orfanos and Ruska 1968a with photos conveniently reproduced in Baden 1990), we compare the development of human hair cuticular cells, which are similar to Erethizon cuticular quill cells (D.M. Chapman, unpublished observations) with the development of the PFCC in Chaetomys. The different developmental pathways are shown in Figures 1a and b and are summarized in Table 1.

\section{Development of the PFCC}

The differentiated stage of the pitted layer is explained on the basis of two developmental phenomena. The first phenomenon in Chaetomys quill development is the imprinting of the inner root sheath (IRS) on the quill's cuticular surface, which must be soft then harden somewhat (Fig. 3b). The soft stage results from properties of early intermediates in the keratins' polymerization and anchoring processes (see below). The IRS outline (Fig. 2g) corresponds to its imprint on the quill's cuticular surface (Figs. $3 a$ and b). Even the tiny bumps making up the microsculpturing on the IRS make their corresponding imprints, which become tiny dimples. Such imprinting was noted by Swift $(1997 ; 1981)$ on the much smaller cuticular cells of the human hair.

The second phenomenon is the appearance of pores and pits (Figs. 2d,e and 3a). By deduction we envisage swelling of the cuticular scales (Fig. 2d) by the early soft keratin, which then hardens to a degree. The entrapped scales of the IRS thus account for the pores and pits. The surface pattern of the pitted region will have two very different types of outlines: the faint junctions between cortical scales and the imprints from the IRS. 
The PFCC scales' borders (Figs. 3a and b) are not obvious. They were originally brought to light by a sub-tangential a slice of the pitted layer (Figs. 4a and b). Partial maceration with paratoluene sulfonic acid (Kassenbeck 1979) makes the borders of the scale clear (Fig. 2b). A cortical scale (i.e. cuticular cell) in a human hair is derived from a single cell, but in Chaetomys a cuticular cell in the pitted layer produces about six scales. A scale-forming cell (PFCC) has, therefore, a superficial scale part and a deeper fibrillous part.

The cells of the inner root sheath are also based on the same plan, namely, a basal plate supporting raised, slanted cuticular processes (Fig. 2f).

Both the human inner root sheath and hair cuticles interlock as do these layers in Chaetomys, but the latter species has undergone an enormous cytological elaboration (Fig. 1b) yet both are organized according to a common plan. The whole sequence is easier to grasp by consulting Figs. 1b,c,d and e.

\section{Role of the keratins}

The keratins play a central role in the structuring and development of the Chaetomys quill. They are a family of fibrous structural proteins that aggregate to form the intermediate fibers (IFs). The IFs are stabilized internally by non-covalent bonds, primarily hydrophobic interactions. The keratin networks can also form covalent cross-linkages of disulfide bonds (Alberts et al. 2015). In the human genome, 16 keratins are specific to hair and nails and are sequentially expressed during development (Langbein et al. 2001). In the hard material of hairs, the keratin filaments are surrounded by keratin-associated proteins (KAPs) capable of crosslinking with the former via disulfide bonds (Langbein and Schweizer 2005; Rogers et al. 2006; Moll et al. 2008). 
Bornschlogl et al. 2016 studied the mechanics of stiffening in the human hair follicle by atomic force microscopy. They found the initial stiffening followed from increasing thickening, compaction, and parallel orientation of the keratin filaments. Stiffening at later stages resulted from the development of cystine cross-linkages between the keratins and the cysteine-rich KAPs. Since mammalian quills and hairs are homologous structures, we hypothesize similar factors at work in quill development in Chaetomys, as for instance during the appearance of pores and pits in the PFCC, where a cuticular cell composed of soft keratins presses against the hard surface of the inner root sheath, then undergoes keratinization and hardening.

Keratins show a range going from soft to hard, a distinction preserved in the consensus nomenclature of 2006 for mammalian keratins (Schweizer et al. 2006). The orange result with staining with Orange $\mathrm{G}$ and Phloxine $2 \mathrm{R}$ indicates the pitted layer tends towards the softer orange variety (Dane and Herman 1963). Both the porosity and moderately hardened pitted layer account for its chalky nature as mentioned above.

\section{Microscopy and Cytology}

\section{Quill-tip barbs}

We confirm that this quill lacks barbs, unlike the quills of all other New World porcupines (Robert Voss, pers. communication). This gives further physical evidence for the high degree of phylogenetic differentiation of Chaetomys within its family of Erethizontidae.

\section{Comparisons with Actinomyces}

The fibrils have a striking resemblance to Actinomyces in their measurements and branching. The fibrils are, however, keratinous, intracellular, quite resistant to $\mathrm{NaOCl}$, and lack both spores and the internal structure of bacteria. Fibrils do not stain with Orcein or Nile Blue 
Sulfate as do Actinomyces. Picric acid stains the fibrils yellow as is typical for keratin (Gurr 1952). Actinomycetes do not have the large amounts of sulfur as in keratin. Actinomycetes are not intracellular. The fibrils are, therefore, not Actinomycetes.

\section{Fibrillous orientation}

Near the apex of the fibrillous compartment the parallel fibrils are aligned at right angles (Fig. 4c) to the surface. Deeper in the basal three quarters of the fibrillous compartment, the fibrils are randomly arranged in layers parallel to the quill surface (Figs. 4c and d). The disposition of the fibrils is suggestive of an engineering solution to tensile stresses because fibrils, in general, are aligned in the direction of a tensile force.

\section{Polarizing microscopy}

Polarizing microscopy added little insight to the study. The aligned keratin filaments of the cortex (Orfanos and Ruska 1968b) account for the birefringence. In the PFCC the outer aligned fibrils of the fibrillous compartment account for its birefringence.

\section{Histochemistry and Chemistry}

Both EDX and Fourier Transform Infrared Spectrometry (Fig. 5) give evidence for a keratinous nature of the pitted and fibrillous layers of the PFCCs. The usual thin hair cuticle (e.g. human) is keratinous and has an epicuticle as does Chaetomys. The PFCC is another cuticular cell, but a highly specialized thick one.

The linings of the contiguous pitted layer (epicuticle: performic acid/Alcian Blue positive) and the fibrillous compartment (Phloxine $2 \mathrm{R}$ positive) were seen to be chemically different. 
The Feulgen reaction showed that the pitted cell dies after differentiation well before emergence. This programmed cell death is characteristic of keratin-producing cells hence the cell is only functional after it dies.

The presence of melanin even in moderate amounts in the hair cuticle of the PFCC is remarkable because in other mammals the occurrence here is either meager or lacking (Hausman 1944). In the usual case, the follicle's bulb is indented to accommodate the dermal papilla, which has a scattered lining of melanocytes (Fawcett 1994). The melanocytes produce melanosomes, then use their dendritic processes to transfer their melanosomes to the precursors of the cortex and medulla, but the presumptive cuticle of the cortex is too far lateral to receive melanosomes except rarely. In Chaetomys, on the other hand, there is no well-formed bulb (D.M. Chapman, unpublished data) and presumably the different cellular arrangement allows melanosome uptake by the developing cuticle of the cortex.

\section{Summary of Remarkable and Unsolved Features}

The PFCC is remarkable in having two layers, a superficial pitted scaled layer and a deeper fibril-containing one, which contains one or two nuclei. This division is also apparent from the way the scale's epicuticle stops at the outer scaled compartment to continue as a chemically different one in the fibrillous compartment. This suggests the PFCC may have been formed as a result of fusion of two distinct precursor cell types, namely one large basal cell and about six scale cells. However, earlier quill developmental stages near the quill's root tip did not show any fusion of cells to account for the PFCC. Therefore, we believe the PFCC is formed as a single cell.

In addition, comparative cytology offers examples of cells with hybrid characteristics that are formed as single cells. Large cells such as hepatocytes may be binucleate (Young et al. 2006), 
but are not formed as the result of cell fusion. Animal histologists recognize four major cell types: nerve, muscle, epithelium and connective (Fawcett 1994). Yet there exist cells that combine these cell features, while being formed as single cells: the cnidarian epitheliomuscular cell with an epithelial and a muscular part (Chapman 1974); and, nematodes with some muscle cells that send out an axon-like process (Stretton 1976).

The cuticles of most mammalian hairs versus that of the PFCC are vastly different. The thickness of the human cuticle is $\sim 0.5 \mu \mathrm{m}$ (Baden 1990; Orfanos and Ruska 1968a) whereas the cuticle of the PFCC is $\sim 20 \mu \mathrm{m}$ thick, a forty fold difference. The PFCC has two layers, a superficial multi-scaled one with a deeper fibril-containing compartment: the usual type of cuticle is a single scale.

The formation of the quill's pits is new to the literature. The PFCC and its inner root sheath both have the uncommon raised type of scales. The $\sim$ six soft transverse broad scales of the PFCC swell to surround the slender scales of the inner root sheath. The scales of the IRS degenerate thus producing pits. Hausman 1944 illustrates eleven raised cuticle types and they are all from bats. Altringham and Fenton 2003 have illustrations of raised cuticle types in bats and point out how a raised cuticle allows the hair to be a more effective osmetrichium which is a stiffened, erectable hair with an enlarged surface area adapted for odorant dispersal (Li et al. 1997). Perhaps pits could act in this capacity; arguing against this possibility is the fact that the skin glands in Chaetomys are few and tiny, and their secretion odorless to the human nose.

In other mammals the inner root sheath disintegrates in the hair follicle just before the opening of the sebaceous gland, but in Chaetomys this sheath is often retained in the emerged quill until it is rubbed off (Fig. 2i). It is easy to mistake some sheath-covered quills with normal 
desheathed ones. We are not aware of other such cases of retained inner root sheath; also, as far as we know, the inner root sheath is unique in having several jutting scales per cell.

Usually, the hair cuticle contains little or no melanin, but here there is enough to lightly color the quills tan. Melanin in most hairs is most abundant in the cortex.

There are grounds for considering this one of the most complex cells known. This claim is based on the cell's unique shape, contents and development.

The function of the PFCC at present remains unknown.

\section{Acknowledgements}

DMC thanks the Departments of Biology and Chemistry of Lakehead University for facilities. Dr Steven D. Kinrade kindly allows me research space in his laboratory.

Mr Michael Sorokopud and Dr Guosheng Wu of the Lakehead University Instrumentation Laboratory provided invaluable service.

GAFG thanks the Coordenação de Aperfeiçoamento de Pessoal de Nível Superior for post-doctoral fellowships (02566/09-5). The Brazilian Environmental Agencies (ICMBio and IBAMA) provided authorization for collection (license number: 23468-1/6) and exportation of biological materials (license number: 15BR017388/DF).

UR thanks Queens College CUNY for use of laboratory facilities. 


\section{References}

Alberts, B.A., Johnson, J., Lewis, D., Morgan, M., Raff, K., and Roberts, P. 2015. Molecular Biology of the Cell. $6^{\text {th }}$ ed. Garland Science, NYC.

Altringham, J.D., and Fenton, M.B. 2003. Sensory ecology and communication in the Chiroptera. In Bat Ecology. Edited by T.H. Kunz and M.B. Fenton. University of Chicago Press Books, Chicago and London. pp. 90-127.

Baden, H.P. 1990. Hair keratin in Hair and Hair Diseases. Edited by C.E. Organos and R. Happle. Springer-Verlag, Berlin and Heidelberg. pp. 45-71.

Bornschlögl, T., Bildstein, L., Thibaut, S., Santoprete, R., Flat, F., Luengo, G.S., Doucet, I., Bernard, B.A., and Baghdadli, N. 2016. Keratin network modifications lead to the mechanical stiffening of the hair follicle fiber. Proc. Natl. Acad. Sci. U.S.A. 113(21): $5940-5945$.

Castilho, L.C., Martinez, R.A., Giné, G.A.F., Ribeiro, G.C., and Schiavetti, A. 2013. The thinspined porcupine, Chaetomys subspinosus (Rodentia: Erethizontidae), within protected areas in the Atlantic Forest, Brazil: local knowledge and threats. Trop. Conserv. Sci. 6(6): 796-810.

Chapman, D.M. 1974. Cnidarian histology. In Coelenterate Biology. Reviews and New Perspectives. Edited by L. Muscatine, and H.M. Lenhoff. Academic Press, Inc., New York, San Francisco and London. pp. 1-92.

Chapman, D.M., and Roze, U. 1997. Functional histology of quill erection in the porcupine, Erethizon dorsatum. Can. J. Zool. 75: 1-10.

Chiarello, A.G., Passamani. M., and Zortéa, M. 1997. Field observations of the thin-spined porcupine, Chaetomys subspinosus (Rodentia: Echimyidae). Mammalia, 61: 29-36. 
Cho, W.K., Ankrum, J.A., Guo, D., Chester, S.A., Yang, S.Y., Kashyap, A., Campbell, G.A., Wood, R.J., Rijal, R.K., Karnik, R., Langer, R., and Karp, J.M., 2012. Microstructured barbs on the North American porcupine quill enable easy penetration and difficult removal. Proc. Nat. Acad. Sci. U.S.A. 1109(52): 21289-94. doi:10.1073/pnas.1216441109

Dane, E.T., and Herman, D.L. 1963. Haematoxylin-phloxine-alcian blue-orange G differential staining of prekeratin, keratin and mucin. Stain Technol. 38: 97-101.

De Souto Lima, R.B., Oliveira, P.A., and Chiarello, A.G. 2010. Diet of the thin-spined porcupine (Chaetomys subspinosus), an Atlantic forest endemic threatened with extinction in southeastern Brazil. Mamm. Biol. 75: 538-46.

Eisenberg, J.F., and Redford, K.H. 1999. Mammals of the Neotropics, Vol. 3. The Central Neotropics: Ecuador, Peru, Bolivia, Brazil. Chicago. The University of Chicago Press. 609 pp.

Elias, H., and Bortner, S. 1957. On the phylogeny of hair. Am. Mus. Novit. No. 1820: 1-15.

Emmons, L.H., and Feer, R. 1997. Neotropical rainforest mammals: a field guide. $2^{\text {nd }}$ ed. Chicago: University of Chicago Press. 307 pp.

Fawcett, D.W. 1994. Bloom and Fawcett. A Textbook of Histology. 12 ${ }^{\text {th }}$ ed. W.B. Saunders Co., Philadelphia, London, Toronto, Rio de Janeiro, Mexico City, Sydney, Tokyo, Hong Kong. Forslind, B. 1990. The growing anagen hair. In Hair and Hair Diseases. Edited by C.E. Orfanos and R. Happle. Springer-Verlag Berlin, Heidelberg. pp. 73-97.

Galigher, A.E., and Kozloff, E.N. 1964. Essentials of Practical Microtechnique. Lea and Febiger, Philadelphia. 
Giné, G.A.F., Duarte, J.M.B., and Faria, D. 2010. Feeding ecology of a selective herbivore, the thin-spined porcupine (Chaetomys subspinosus) in the Atlantic Forest. J. Mammal. 91: 931-941.

Giné, G.A.F., Duarte, J.M.B., Motta, T.C.S., and Faria, D. 2012. Activity, movement and secretive behavior of a threatened arboreal folivore, the thin-spined porcupine, in the Atlantic forest of southern Bahia, Brazil. J. Zool. (Lond.) 286: 131-139.

Grimstone, A.V., and Skaer, R.J. 1972. A Guidebook to Microscopical Methods. Cambridge University Press, Cambridge.

Gurr, E. 1952. A Practical Manual of Medical and Biological Staining Techniques. Interscience Publishers, Inc. New York.

Hashimoto, K. 1988. The Structure of Human Hair. Clin. Dermatol. 6: 7-21.

Hausman, A. 1944. Applied microscopy of hair. Sci. Mon. 59: 195-202.

Humason, G.L. 1979. Animal Tissue Techniques. $4^{\text {th }}$ ed. W.H. Freeman, San Francisco and London.

Junqueira, L.C., and Carneiro, J. 2005. Basic Histology. ${ }^{11 \text { th }}$ ed. McGraw -Hill, New York.

Kassenbeck, P. 1979. Morphology and fine structure of hair. In Hair Research. Status and future aspects. Edited by C.E. Orfanos, W. Montagna, and G. Stüttgen. Springer, Berlin. pp. 5264.

Langbein, L., Rogers, M.A., Winter, H., Praetzel, S., and Schweizer, J. 2001. The catalog of human hair keratins. II. Expression of the six members in the hair follicle and the combined catalog of human type I and II keratins. J. Biol. Chem. 276: 35123-35132.

Langbein, L., and Schweizer, J. 2005. Keratins of the human hair follicle. Int. Rev. Cytol. 243: 178. 
Li, G., Roze, U., and Locke, D. C. 1997. Warning odor of the North American Porcupine (Erethizon dorsatum) J. Chem. Ecol. 23: 2737-2754.

Lillie, R.D. 1955. The basophilia of melanin. J. Histochem. Cytochem. 3: 453-4.

Moll, R., Divo, M., and Langbein, L. 2008. The human keratins: biology and pathology. Histol. Cell Biol. 129(6):705-733.

Nation, J.L. 1983. A new method using hexamethyldisilazane for preparation of insect soft tissue for scanning electron microscopy. Stain Technol. 58: 347-351.

Nowak, R.M. 1999. Walker's Mammals of the World. $6^{\text {th }}$ ed. The Johns Hopkins University Press, Baltimore.

Oliveira, P.A., de Souto Lima, R.B., and Chiarello, A.G. 2012. Home range movements and diurnal roosts of the endangered thin-spined porcupine, Chaetomys subspinosus (Rodentia: Erethizontidae), in the Brazilian Atlantic Forest. Mamm. Biol. 77: 97-107.

Orfanos, C.E., and Ruska, H. 1968a. Die Feinstruktur des menschlichen Haares. I. Die Haarcuticula. Arch. Klin. Exp. Dermatol. 231: 97- 110.

Orfanos, C.E., and Ruska, H. 1968b. Die Feinstruktur des menschlichen Haares. I. Die HaarCortex. Arch. Klin. Exp. Dermatol. 231: 264-278.

Pearse, A.G.E. 1968. Histochemistry: Theoretical and Applied. J and A Churchill Ltd., London. Pontes, A.R.M., Gadelha, J.R., Melo, E.R.A., de Sá, F.B., Loss, A.C., Junior, V.C., Costa, L.P., and Leite, Y.L.R. 2013. A new species of porcupine, genus Coendou (Rodentia, Erethizontidae) from the Atlantic forest of northeastern Brazil. Zootaxa, 3636(3): 421-438. Ribeiro, M.C., Metzger, J.P., Mortensen, A.C., Ponzoni, F.J., and Hirota, M.M. 2009. The Brazilian Atlantic Forest. How much is left, and how is the remaining forest distributed? Implications for conservation. Biol. Conserv. 142:1141-1153. 
Rogers, M.A.L., Langbein, S., Praetzel-Wunder, H., Winter, H., and Schweizer, J. 2006. Human hair keratin-associated proteins (KAPs). Int. Rev. Cytol. 251: 209-263.

Roze, U. 2002. A facilitated release mechanism for quills of the North American porcupine (Erethizon dorsatum). J. Mammal. 83(2): 381-385.

Roze, U. 2009. The North American Porcupine. $2^{\text {nd }}$ ed. Cornell University Press, Ithaca, NY.

Roze, U. 2012. Porcupines: the Animal Answer Guide. The Johns Hopkins University Press, Baltimore.

Santos, I.B., Oliver, W.L.R., and Rylands, A.B. 1987. Distribution and status of two species of tree porcupines, Chaetomys subspinosus and Sphiggurus insidiosus, in south-east Brazil. Dodo: Journal of the Jersey Wildlife Preserve Trust 24: 43-60.

Schweizer, J., Bowden, P.E., Coulombe, P.A., Langbein, L., Lane, E.B., Magin, T.M., Maltais, L., Omary, M.B., Parry, D.A., Rogers, M.A., and Wright, M.W. 2006. New consensus nomenclature for mammalian keratins. J. Cell Biol. 174(2): 169-174.

Stretton, A.O. 1976. Anatomy and development of the somatic musculature of the nematode Ascaris. J. Exp. Biol. 64: 773-788.

Swift, J.A. 1981. The hair surface. In Hair Research. Edited by C.E. Orfanos, W. Montagna, and G. Stüttigen. Springer Verlag, Berlin, pp. 65-72.

Swift, J.A. 1997. Human and other animal hair: morphological and functional comparison. Retinoids, 13(4): 114-119.

Vilela, R.V., Machado, T., Ventura, K., Fagundes, V., de J Silva, M.J., and Yonenaga-Yasuda, Y. 2009. The taxonomic status of the endangered thin-spined porcupine, Chaetomys subspinosus (Olfers, 1818), based on molecular and karyological data. BMC Evol. Biol. 9: 
29. Available from htpp://www.biomedcentral.com/1471-2148/9/29 [accessed 16 January 2017].

Voss, R.S. 2011. Revisionary notes on neotropical porcupines (Rodentia: Erethizontidae), 3: An annotated checklist of the species of Coendou Lacépède, 1799. Am. Mus. Novit. No.3720: $1-36$.

Voss, R.S., Hubbard, C., and Jansa, S.A. 2013. Phylogenetic relationships of New World porcupines (Rodentia, Erethizonidae): implications for taxonomy, morphological evolution, and biogeography. Am. Mus. Novit. No. 3769: 1-36.

Wigglesworth, V.B. 1971. Bound lipid in the tissues of mammal and insect: a new histochemical method. J. Cell. Biol. 8:709-25.

Young, B., Lowe, J.S., Stevens, A., and Heath, J.W., 2006. Wheater's Functional Histology. A Text and Colour Atlas. $5^{\text {th }}$ ed. Churchill Livingstone Elsevier Ltd. Glasgow UK 


\section{Table 1 Cuticular morphology comparison}

The hair cuticular cell

\begin{tabular}{lc} 
Cell is a thin irregular rectangular prism & Cell is mainly a thick hexagonal prism \\
\hline No basal fibrillous compartment & Basal fibrillous compartment present \\
\hline Each cell is a scale & Surface with 6 scales per PFCC \\
\hline Slight scale slant with respect to shaft & Greater angle between scale and shaft \\
\hline Inner root sheath cuticular cell like a hair's cuticular cell & A single inner root sheath cell with several strap-like processes
\end{tabular}




\section{Figure captions}

Fig. 1a Drawing of a neck quill. The stippled part is the pitted region. The short tip at right is not pitted. Arrow points to the anchoring end. Bar $=1 \mathrm{~cm}$.

(b) Chaetomys. Side view of the developing PFCC at early and later stages. Early stage: Raised cuticular scales of the inner root sheath (IRS) insert in grooves between the raised quill cuticular scales as per the 'Early surface view.' In the later stage, the soft cuticular scales swell to surround the cuticular scales of the IRS as per the 'Later surface view.' A cuticular cell of the hair $(\mathrm{Cx})$ in Fig. 1f corresponds to the whole PFCC in Fig. 1b: the cuticle of the inner root sheath (Ci) in Fig. 1e corresponds to the cuticle of the inner root sheath (IRS) in Fig. 1b top left). (c) A view of the PFCC from above and to the side to show the quill's cuticular cortical scales before swelling. The scales tilt at $65^{\circ}$ to the shaft. The PFCC is basically a hexagonal or pentagonal prism. At right, the later stage after swelling.

(d, above) The IRS cuticle is simple squamous with several spatulate, slanted, raised scales. (d, below) An IRS cuticular cell with three scales two of which have been cut to show their crosssectional profiles. Distal to right.

(e) Details of the differentiated PFCC. The cuticular scales of the inner root sheath (IRS) are inserted in pits. One IRS scale has a segment removed revealing the pit's walls. Later the scales of the IRS disintegrate resulting in empty pits. This sheath makes imprints on the quill surface. Only one imprint is shown. At a pit's base is the opening of the circumferential tunnel (T) connecting other pits (PIT): the $\sim 12-\mu \mathrm{m}$ thick pitted layer showing fusion (F) of the scales: the $\sim 10$ - $\mu \mathrm{m}$ thick fibrillous layer $(\mathrm{Fb})$. The fibrils are radial at the pit's bottom, but deeper in they extend horizontally in different directions. The fibrils become more compacted basally. The large black dots represent melanosomes. Distal to right. 
(f) Stereogram of a developing human hair follicle, which is the same as in an Erethizon quill's follicle. The cuticle $(\mathrm{Cx})$ of the hair's cortex starts off as a single layer of hexagonal prismatic cells (but cuboid in section) then the cells flatten, tilt, keratinize and die, but are retained. The cuticle of the inner root sheath $(\mathrm{Ci})$ interlocks with the cuticle of the cortex $(\mathrm{Cx})$. CT, connective tissue; Hn, Henle's layer; Hx, Huxley's layer; *, degeneration of the scales of the IRS; ORS, outer root sheath.

Fig. 2a Four regional quills: top, head; $2^{\text {nd }}$, neck; $3^{\text {rd }}$, upper back; $4^{\text {th }}$, mid-back. Distal ends at right.

(b) Partial maceration with paratoluene sulfonic acid demonstrates the scale outlines clearly. Distal is down.

(c) The pre-pitted layer region and its relationships. The spatulate cuticular scales of the inner root sheath (I) interdigitate with the quill's cuticular scales (C). Rounded pits have not yet formed. Distal to left.

(d) Pits form once the cuticular cortical scales surround the cuticular scales of the inner root sheath except for the tunnel opening. The sheath complex and its scales have traumatically and fortuitously separated from the pitted layer during microdissection. An inner root sheath scale is usually pulled out intact despite its distal flare thus indicating its softness. Distal to left. (e) Pits in pitted region. Circumferential tunnel at white arrow.

(f) The pre-definitive inner root sheath with its cuticular scales, which insert into the pitted layer, has been peeled off revealing their raised flared spatulate cuticular nature. Some torn-off ones demonstrate their cylindrical bases. Distal is up.

(g) These cuticular inner root sheath scales have been torn off leaving their scars. The intact surface has tiny bumps with cell outlines at arrows. There are several scales per cell outline. 
(h) The pits and inner root sheath scales are cut in cross-section. Note the $0.4-0.5-\mu \mathrm{m}$ thick pit's epicuticular layer and a melanosome (black arrow) in the cytoplasm. One melanosome has fallen out (white arrow).

(i) The inner root sheath can be retained to various degrees on emerged quills and hairs. Here the sheath is shedding from the pitted region.

Fig. 3a The pitted quill's surface has ridges and troughs resembling cell outlines occurring between irregular rows of pits. Cuticular scale junctions are difficult to see at the black arrows. Distal is down.

(b) The pitted region with the long axis from top to bottom. Distal is down. The white arrow shows one of five inter-scale junctions. The inner root sheath imprints the surface with its outlines (black arrow) and surface texture. The pit contents are disintegrating.

Fig. 4a A blade shaved the outer layer of the pitted layer longitudinally revealing the deep laminar nature of the scales of the pitted layer magnified in Fig. 4b.

(b) Between the lamellar scales at their cracked bases are circumferential grooves. These grooves are longitudinal sections of the grooves in Fig. 2(c) at the stage before pit formation. One cuticular scale side end is indicated by a white arrow in Fig. 4 b.

(c) Junction of the fibrils in the fibrillous part attaching to the base of two pits. Note how the more basal part is more compacted with randomly arranged fusing fibrils whereas the superficial layer has its fibrils arranged in a parallel manner at right angles to the base.

(d) Branching fibrils from the fibrillous compartment. The varied directions are parallel to the cell's base.

(e) Surface view of the fibrillous part of the PFCC as revealed by $\mathrm{NaOCl}$. Note the former locations of nuclei. The cells are often binucleate. 
Fig. 5. Fourier Transform Infrared scan of human nail $(\mathrm{N})$ and pitted $(\mathrm{P})$ surface of Chaetomys. The $\mathrm{CO}_{2}$ artifact is labelled $\mathrm{A}$. Absorbance (Y-axis) versus wavelength nm (X-axis). 
(a)
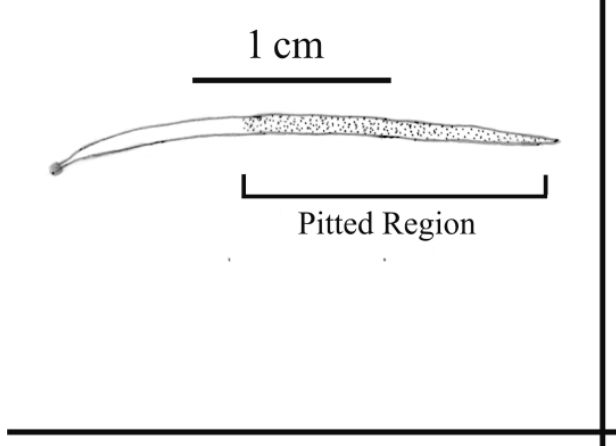

(c)
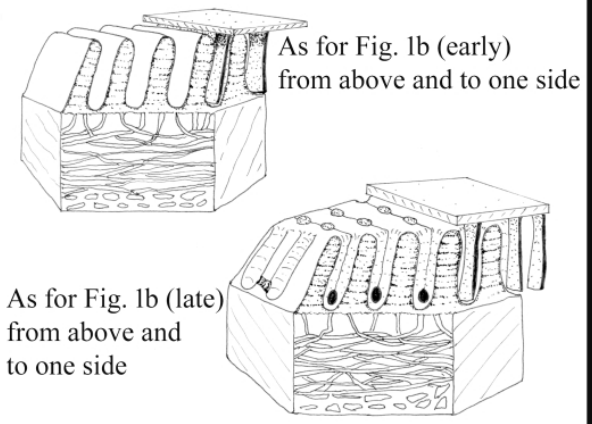

(e)

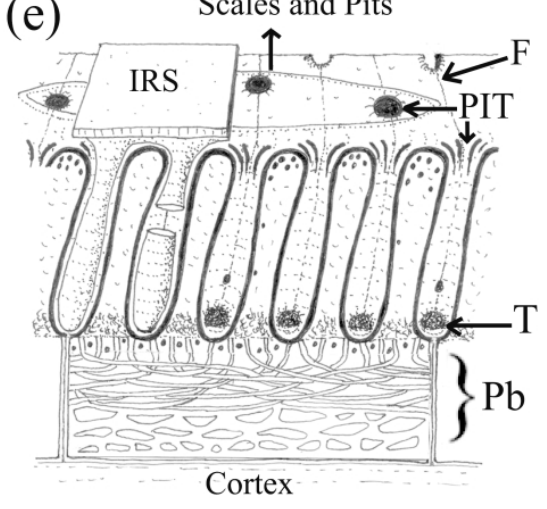

(b) Early Stage Late Stage

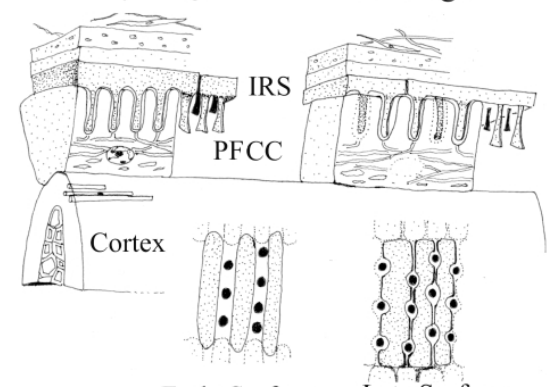

Early Surface Late Surface View View

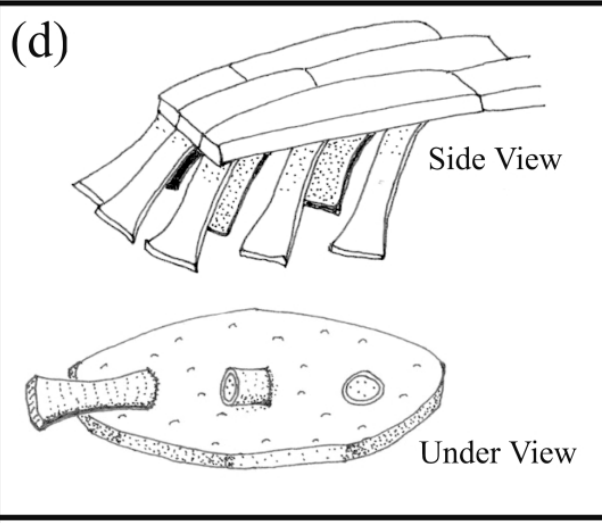

(f)

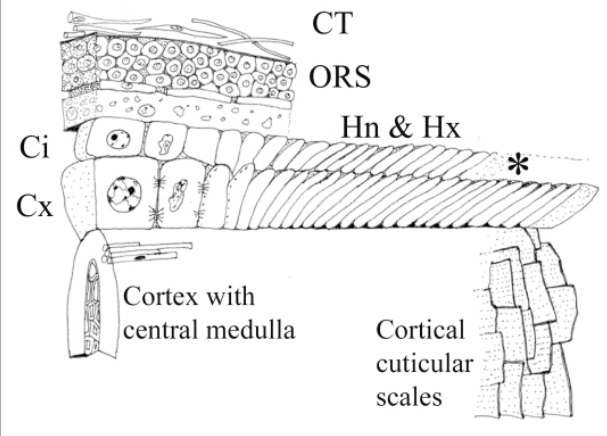

Figure 1 


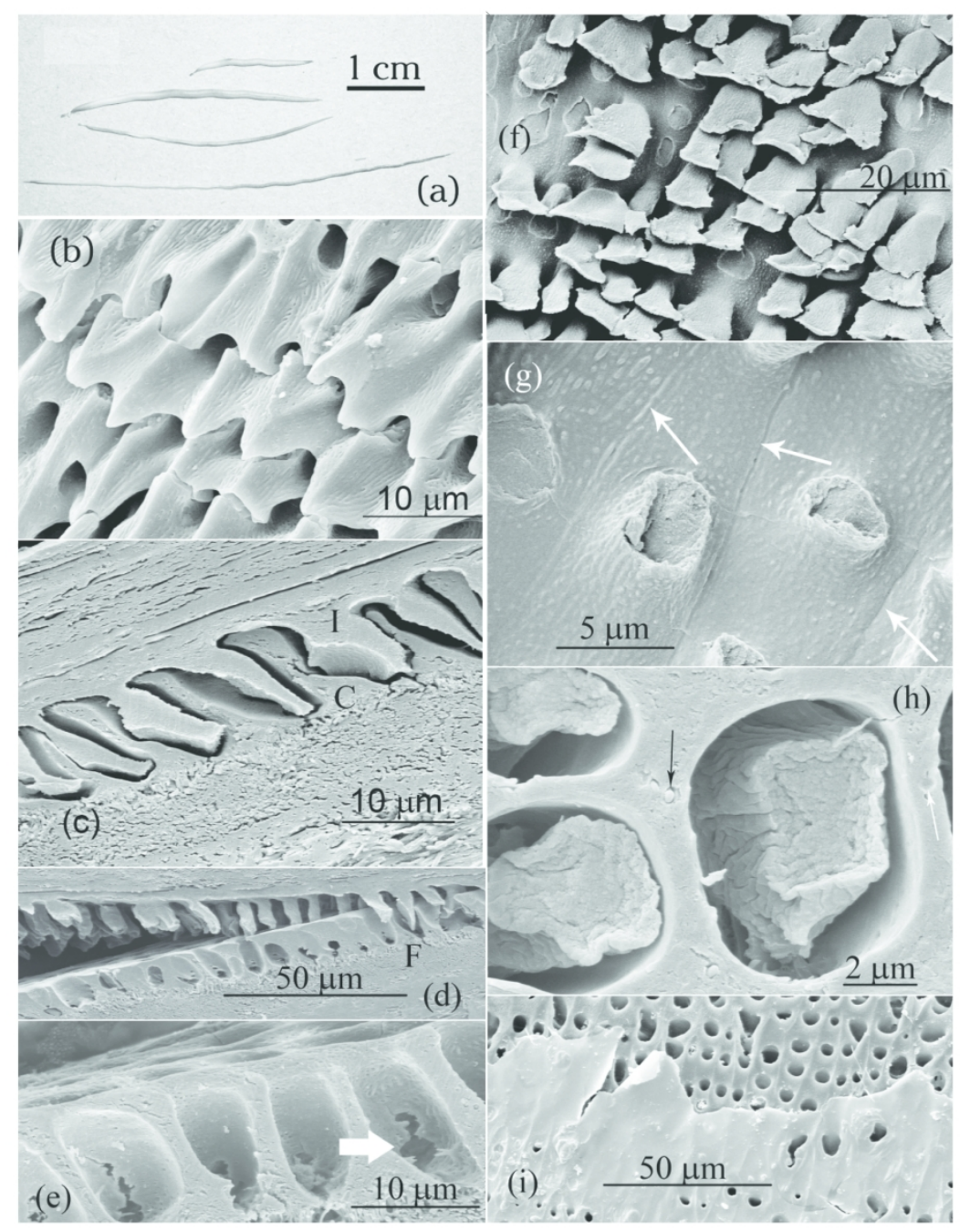

Figure 2

Figure 2.

$183 \times 255 \mathrm{~mm}(300 \times 300 \mathrm{DPI})$ 


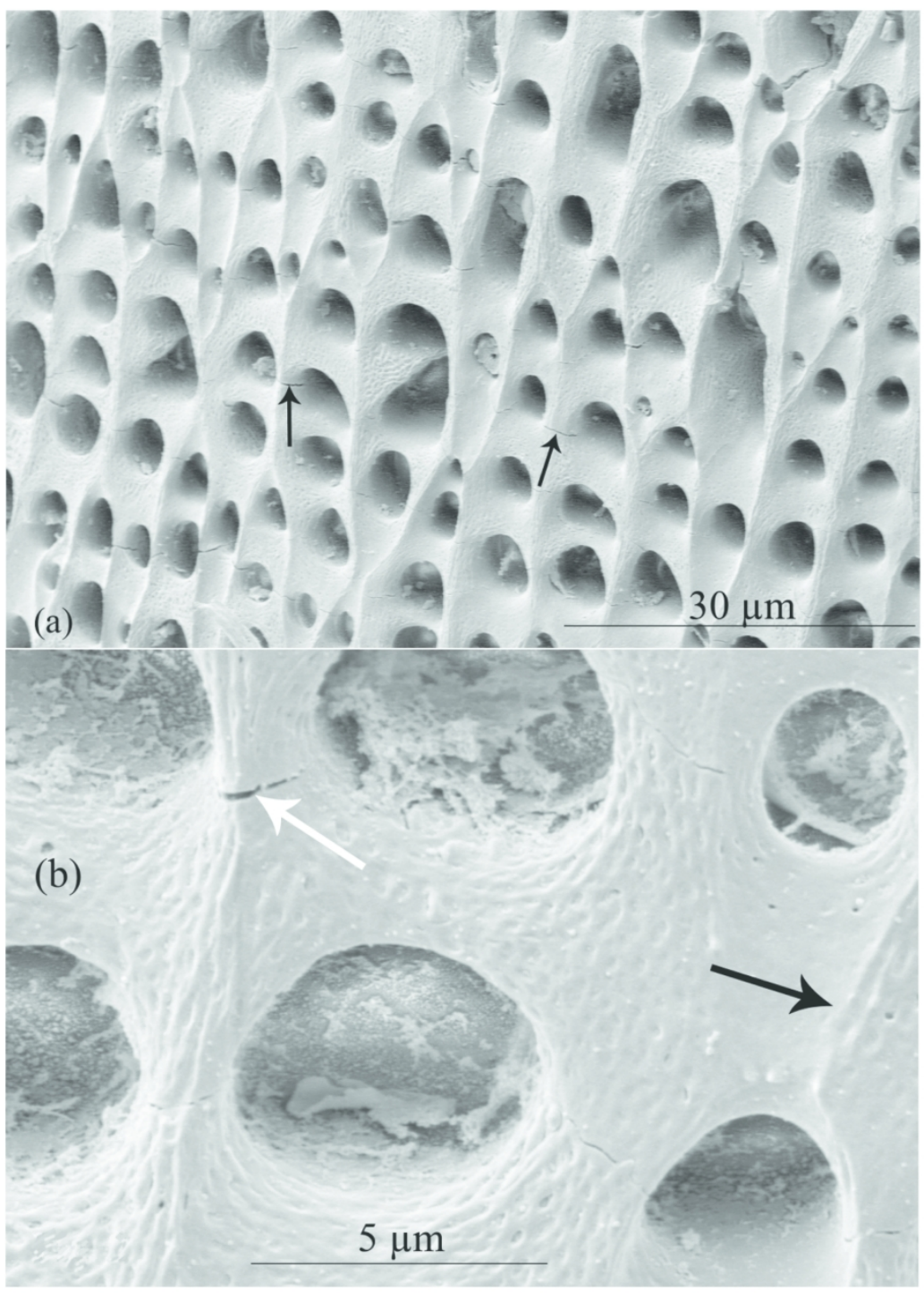

Figure 3

Figure 3.

$197 \times 252 \mathrm{~mm}(300 \times 300 \mathrm{DPI})$ 


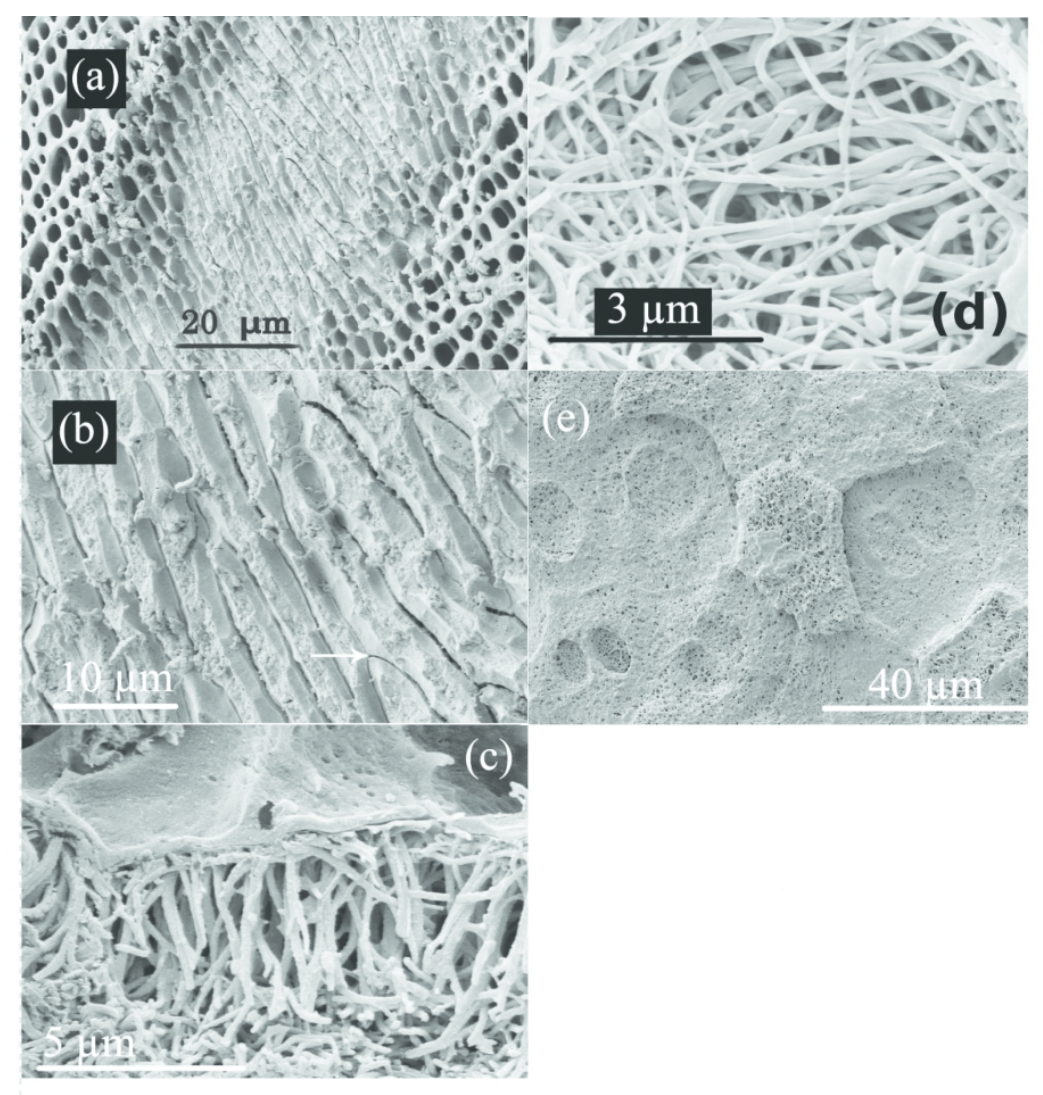

Figure 4

Figure 4.

$183 \times 255 \mathrm{~mm}(300 \times 300 \mathrm{DPI})$ 


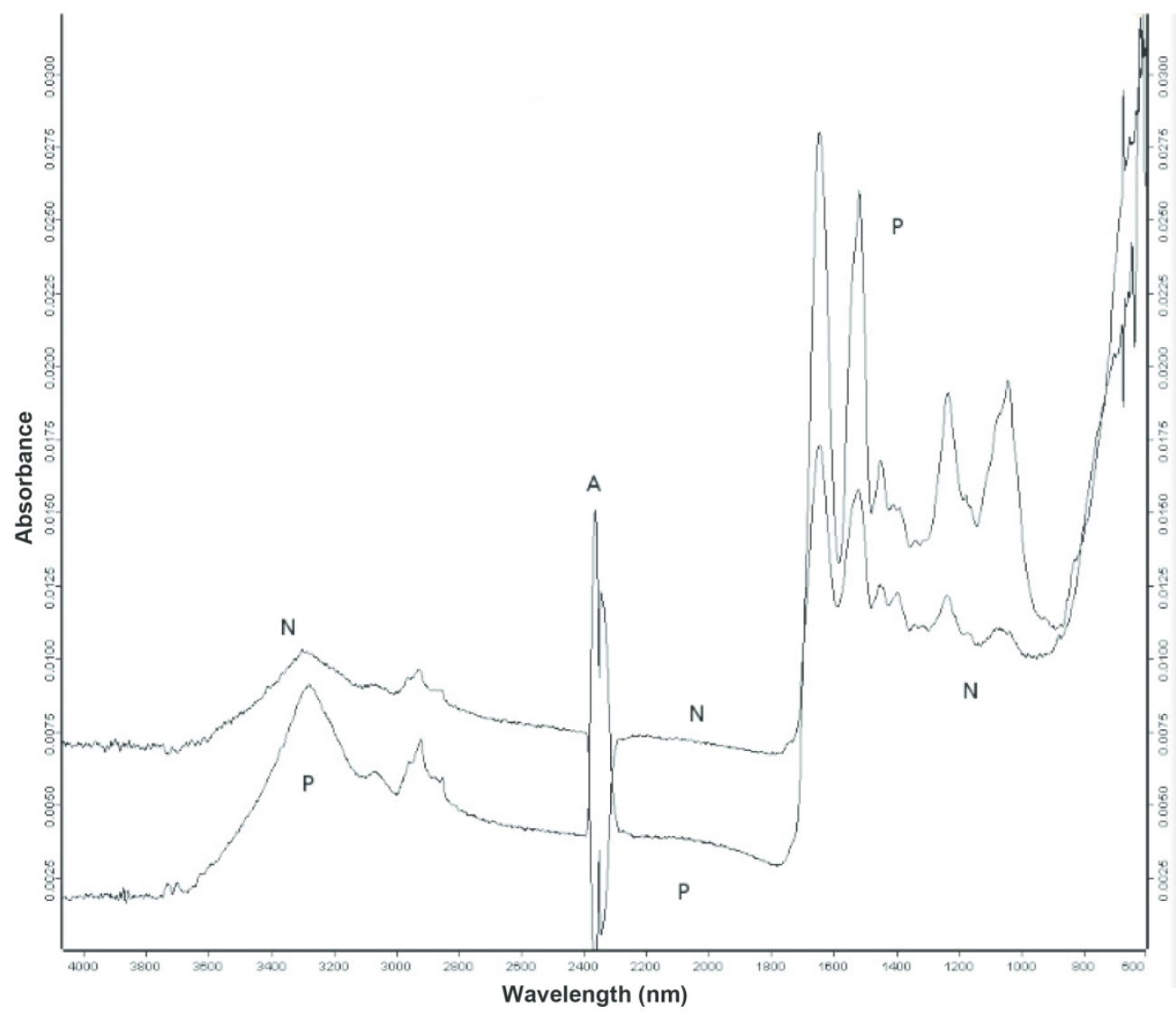

Figure 5

Figure 5.

$197 \times 229 \mathrm{~mm}(300 \times 300 \mathrm{DPI})$ 